\title{
Brown Swiss cows are more heat resistant than Holstein cows under hot summer conditions of the continental climate of Ukraine
}

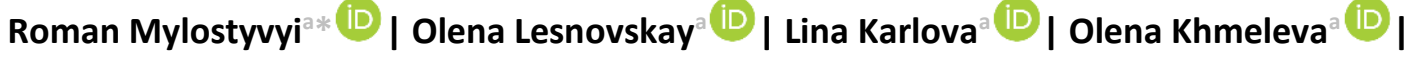 \\ Olena Kalinichenko (iD) | Oksana Orishchuk ${ }^{a}$ (ID) Svitlana Tsap ${ }^{\text {(iD }}$ | Natalia Begma ${ }^{\text {(iD) }}$ \\ Nikolay Cherniy ${ }^{b}$ | Bogdan Gutyj ${ }^{(\text {iD }}$ | Olena Izhboldina
}

aDnipro State Agrarian and Economic University, Sergii Efremov Str., 25, Dnipro, 49600, Ukraine.

${ }^{b}$ Kharkiv State Zooveterinary Academy, Academic Str.1, Mala Danylivka, Kharkiv region, 62341, Ukraine.

Stepan Gzhytskyi National University of Veterinary Medicine and Biotechnologies, Pekarska Str., 50, Lviv, 79010, Ukraine.

*Corresponding author: mylostyvyi.r.v@dsau.dp.ua

\begin{abstract}
Finding livestock breeds that are resistant to high temperatures may be one of the strategies for mitigating the impact of global climate change on dairy farming. In this investigation, we studied the heat resistance of Holstein (HB) and Brown Swiss (BS) cows on two commercial dairy farms under the hot summer conditions of Ukraine. The physiological response of animals determined heat resistance by measuring rectal temperature (RT) and respiratory rate (RR) in the morning (from 4:00 to 6:00) in comfortable conditions and the afternoon (from 14:00 to 16:00), during heat load. The temperature-humidity index (THI) was used to characterize weather conditions and microclimate in naturally ventilated rooms (NVBs). BS cows were found to be heat resistant. The reaction of HB cows to the heat was manifested by higher growth of RT and RR, and they suffered significant losses in the daily milk yield per cow in the summer. Further research will need to elucidate the biological and genetic mechanisms of the identified breed differences in heat tolerance of dairy cows.
\end{abstract}

Keywords dairy cattle, milk productivity, physiological parameters, thermal tolerance

\section{Introduction}

Global climatic changes, weather variability, and periods of extremely high temperatures in summer are becoming a problem for territories with a tropical climate and a temperate continental climate typical for most European countries (Tomczyk et al 2019). Longer heat waves, which are increasingly recorded during warm periods of the year, lead to a decrease in milk yield and tangible economic losses (Ferreira et al 2016).

Selecting animals that are more resistant to high temperatures may be one of the strategies for mitigating the effects of climate change. Numerous studies indicate the breed features of the heat resistance of cows (Gantner et al 2011; Smith et al 2013; Daltro et al 2017). As a rule, local aboriginal cattle are more resistant than high-yielding dairy breeds, the metabolism of which is associated with high heat production and the difficulty of maintaining isothermia in hot environmental conditions (Bernabucci et al 2014). Therefore, they are more prone to manifestation of heat stress (Das et al 2016).

Physiological adaptability is considered one of the primary response mechanisms that allow animals to survive (Rashamol et al 2018). Respiratory rate (RR) and pulse rate, rectal temperature (RT), degree of sweating, and skin temperature are physiological parameters that help maintain heat balance and homeostasis during hyperthermia (Abdela and Jilo 2016).

The use of physiological parameters such as time, rectal temperature, and respiratory rate of animals under temperature load remains a simple and available method for assessing the heat resistance of animals (Daltro et al 2017), along with complex metabolic markers of heat stress in dairy cows, which are actively used in recently (Kim et al 2018). Determination of the heat resistance of individual breeds should be the initial stage for selecting animals and further clarification of the nature of their adaptive capabilities and the ability to maintain high productivity under extreme weather. According to scientists' forecasts, only under such conditions can one count on success, relying on long-term breeding strategies and the creation of animals that are resistant to global climate change, the consequences of which will increasingly be felt for dairy farming in the future, according to scientists' forecasts (Wangui et al 2018). Thus, the work aimed to investigate the heat resistance of the organism and the productivity of Holstein (HB) and Brown Swiss (BS) cows during the summer heat.

\section{Materials and Methods}




\subsection{Animals}

The research was carried out as part of the research project of the Dnipro State Agrarian and Economic University, "Ensuring sustainable development of animal husbandry and natural resistance under the influence of environmental and technological factors" (state registration number 0114U005590).

This experiment was conducted following the requirements for humane treatment of animals and approved by the Bioethics Commission of the Institute of Biotechnology and Animal Health. The research was carried out in the summer of 2018. The study was conducted on two commercial dairy farms in Ukraine, where livestock of the

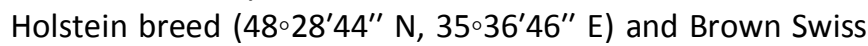
$\left(48^{\circ} 34^{\prime} 03.1^{\prime \prime} \mathrm{N}, 34^{\circ} 54^{\prime} 47.0^{\prime \prime} \mathrm{E}\right)$ are bred. Groups of animals were formed from re-giving birth dairy cows of average lactation (days in milk from 91 to 210). The daily milk yield of Holstein cows (HB, $n=31$ ) was $25.4 \pm 0.19 \mathrm{~kg}$, of Brown Swiss cows (BS, $n=31$ ), it was from $27.3 \pm 0.22 \mathrm{~kg}$.

\subsubsection{Keeping and feeding cows}

The conditions for keeping and feeding the cows were similar. In short, free-stall housing was used for lactating cows in naturally ventilated barns (NVBs). Sand or rugs were used as bedding in the cubicles. The cows were fed a general mixed ration based on corn silage. The diets were balanced in essential nutrients, according to the National Research Council (NRC 2001). The cattle-breeding housing included feed alleys and group drinkers with free access. Conditions for keeping cows have been described in more detail in our previously published study (Mylostyvyi et al 2020).

\subsection{Weather conditions}

The territory on which the dairy farms are located, according to the Köppen climate classification, refers to a humid continental climate with hot summers (Dfa). Weather data from the nearest meteorological stations were taken on the website of the Ukrainian Hydrometeorological Center, as we described earlier (Mylostyvyi and Chernenko 2019). Weather data were taken into account throughout the day during the study, during the week, and the month preceding the study.

\subsubsection{Microclimate of barns}

Indoor air temperature $(\mathrm{AT})$ and relative humidity $(\mathrm{RH})$ were recorded using a thermo-hygrometer (Ambient Weather WS-10, Ambient LLC, Chandler, AZ, USA) throughout the day during the study, continuously placing remote sensors in stalls at animal level. At the same time, the temperature-humidity index (THI), calculated according to Kibler (1964), served as an indicator of heat stress (HS) in cows:

$\mathrm{THI}=1.8 \times \mathrm{T}-(1-\mathrm{RH} / 100) \times(\mathrm{T}-14.3)+32$

where $\mathrm{THI}$ is the temperature-humidity index, $\mathrm{T}$ is the air temperature in ${ }^{\circ} \mathrm{C}$, and $\mathrm{RH}$ is the relative humidity in $\%$.

\subsection{Determination of heat resistance}

The heat resistance of the cows' organism was assessed during the hot period. For this purpose, rectal temperature $\left(\mathrm{RT},{ }^{\circ} \mathrm{C}\right)$ and respiratory rate (RR, breaths/min) were determined from 4:00 to 6:00 in the morning (during the period of thermal comfort) and during maximum air warming from 14:00 to 16:00. Rectal temperature was measured with a VT 1831 Digital veterinary thermometer (Microlife, Switzerland) for 3 minutes. The respiration rate was determined visually by counting the number of chest movements of the cows in the lying position for $30 \mathrm{~s}$ and multiplying the result by two.

Heat resistance (HT), an index combining respiratory rate and rectal temperature at which high values are the worst, was calculated according to Benezra (1954):

$H T=(R T / 38.3)+(R R / 23.0)$

where $\mathrm{RT}$ is body temperature in ${ }^{\circ} \mathrm{C}$ at temperature load; $\mathrm{RR}$ is the respiratory rate per minute at temperature load; 38.3 and 23.0 are the average values of body temperature and respiratory rate in optimal conditions.

The thermal vulnerability index (TVI), which combines the respiratory rate and rectal temperature, at which high values are the worst, was determined according to Dmitriev (1970):

$\mathrm{TVI}=(\mathrm{Td} / \mathrm{Tm})+(\mathrm{Rd} / \mathrm{Rm})$

where $\mathrm{Td}$ is the body temperature of animals in the daytime; $\mathrm{Tm}$ is the body temperature of animals in the morning; $\mathrm{Rd}$ respiratory rate per minute during the day; $\mathrm{Rm}$ - respiratory rate per minute in the morning hours.

\subsection{Milk productivity}

Productivity (daily milk yield $(\mathrm{kg})$, fat, and protein content (\%)) for a herd of HB $(n=756)$ and BS $(n=1300)$ dairy cows were taken into account according to the data of Dairy Comp - 305 - Herd Management Software at each farm from May to September 2018.

\subsection{Statistical analysis}

The statistical software package STATISTICA 10 (StatSoft, Inc., Tulsa, OK, USA) was used for statistical data processing. The distribution of almost all variational series was not subject to the criteria of normality; therefore, in the further analysis, the methods of nonparametric statistics were used. Data are presented as means (Mean) and standard error of the mean (SE). The significance of differences between groups was assessed using the nonparametric Mann-Whitney test. Differences were considered statistically significant at values of $P<0.05$.

\section{Results}

\subsection{Weather conditions}

To maintain optimal physiological functions of the cow's body, the environmental conditions must correspond 
to the limits of temperature comfort for animals, which depends not only on the magnitude of external temperatures but also on humidity, affecting animals' ability to maintain temperature equilibrium.

An equally important point on which the body's response to the effects of weather factors depends is the duration of their exposure to animals. At least three to five days of staying beyond the upper limit of thermoneutrality is required to affect the clinical state of the animals. That is why the data presented (Table 1) characterize the weather conditions on the day of the study and cover the period before and during the week before their actual conduction.

Table 1 Weather conditions according to the data of the nearest weather stations.

\begin{tabular}{|c|c|c|c|c|c|c|c|c|}
\hline \multirow[t]{2}{*}{ Index } & \multicolumn{4}{|c|}{ Holstein Breed } & \multicolumn{4}{|c|}{ Brown Swiss } \\
\hline & Mean & SE & Min & Max & Mean & SE & Min & Max \\
\hline & \multicolumn{8}{|c|}{ Throughout the day during the research } \\
\hline AT & 26.5 & 4.96 & 19.0 & 34.0 & 25.7 & 5.49 & 17.0 & 34.0 \\
\hline $\mathrm{RH}$ & 43.8 & 14.37 & 23.0 & 83.0 & 45.9 & 16.99 & 25.0 & 77.0 \\
\hline \multirow[t]{2}{*}{ THI } & 72.2 & 4.53 & 65.4 & 79.1 & 71.3 & 5.12 & 62.0 & 78.6 \\
\hline & \multicolumn{8}{|c|}{ The day before the research } \\
\hline AT & 26.3 & 4.55 & 19.0 & 33.0 & 24.9 & 5.22 & 18.0 & 32.0 \\
\hline $\mathrm{RH}$ & 46.2 & 11.51 & 30.0 & 68.0 & 53.7 & 11.92 & 38.0 & 73.0 \\
\hline \multirow[t]{2}{*}{ THI } & 72.5 & 4.45 & 64.7 & 78.7 & 71.3 & 5.85 & 63.2 & 79.2 \\
\hline & \multicolumn{8}{|c|}{ During the week before the research } \\
\hline AT & 23.0 & 4.99 & 14.0 & 33.0 & 24.8 & 5.28 & 15.0 & 34.0 \\
\hline $\mathrm{RH}$ & 49.8 & 14.7 & 27.0 & 83.0 & 48.4 & 15.22 & 21.0 & 88.0 \\
\hline THI & 68.4 & 5.44 & 57.3 & 78.7 & 70.6 & 5.63 & 58.7 & 80.0 \\
\hline
\end{tabular}

Note: AT is the air temperature, ${ }^{\circ} \mathrm{C}$; RH is the relative humidity, \%; THI is the temperature and humidity index, units.

Based on the data presented, it can be argued that the weather conditions in which the $\mathrm{HB}$ and BS cows were located were almost the same. In particular, the presented differences in average temperatures and THI per week $\left(1.8^{\circ} \mathrm{C}\right.$ and 2.2 units), per day $\left(1.4^{\circ} \mathrm{C}\right.$ and 1.2 units), and throughout the day during the research $\left(0.8{ }^{\circ} \mathrm{C}\right.$ and 0.9 units), did not have a significant difference.

\subsection{Microclimate in naturally ventilated farm structures during research}

The microclimate parameters of the barns in which the experimental animals were kept were determined by measuring the air temperature and relative humidity, followed by calculating the temperature-humidity index (Table 2).

From the data presented (Table 2), it can be seen that when keeping cows of the $\mathrm{HB}$ and $\mathrm{BS}$, a significant difference was recorded between the morning and daytime indoor temperatures during the day. The temperature difference averaged $13.2^{\circ} \mathrm{C}$ and $10.3^{\circ} \mathrm{C}$, the THI values differed by 11.9 and 10.3 units, respectively $(P<0.05)$. It was much hotter during the day than in the morning.

\subsection{Physiological indicators and heat resistance of animals}

According to the changes in the temperature regime in the barns, the clinical indicators in cows changed (Table 3 ). It was found that under conditions of thermal comfort (in the morning), $\mathrm{HB}$ and BS cows did not differ significantly according to clinical indications (rectal temperature and respiratory rate). However, these indicators in Swiss cows were slightly higher than the average values, by $1.3 \%$ and $4.1 \%$, respectively.

With an increase in the air temperature during the day to $30{ }^{\circ} \mathrm{C}$ in cows of both breeds, the rectal temperature noticeably increased as well the frequency of respiratory movements. At the same time, a more significant increase (by $3.4 \%$ and $35.0 \%$ ) was observed in $\mathrm{HB}$, versus $1.3 \%$ and $28.7 \%$, respectively, in BS animals. That is, the body of HB cows reacted more tangibly to the temperature load by changing clinical parameters.

The heat resistance of the body ensures its adaptive ability, which allows maintaining a high level of milk production in extreme temperature conditions. The heat resistance index (according to Benezra) in animals of the Holstein breed was 3.9\% higher than in the Swiss breed. The heat vulnerability index (according to Dmitriev) in cows of the Holstein breed was also higher than that of the Swiss breed, by 0.14 (5.3\%).

It is logical to assume that the structure of constructing the Benezra and Dmitriev indices determines the inverse relationship between their values and the level of heat resistance. The high level of these indices in animals of the Holstein breed corresponds to their lowest heat resistance.

The level of milk production can confirm this in animals since the ability of animals to maintain their body temperature effectively depends on the effectiveness of thermoregulatory mechanisms, spending the minimum amount of internal energy reserves necessary for the synthesis and secretion of milk. 
Table 2 Microclimate of farm structures during research.

\begin{tabular}{|c|c|c|c|c|c|c|c|c|}
\hline \multirow[t]{2}{*}{ Index } & \multicolumn{4}{|c|}{ Morning } & \multicolumn{4}{|c|}{ Afternoon } \\
\hline & Mean & SE & Min & Max & Mean & SE & Min & Max \\
\hline & \multicolumn{8}{|c|}{ Holstein Breed } \\
\hline AT & 21.1 & 0.67 & 19.4 & 22.3 & $34.3^{*}$ & 0.37 & 33.8 & 35.0 \\
\hline $\mathrm{RH}$ & 52.6 & 2.06 & 50.0 & 56.0 & $25.2^{*}$ & 2.29 & 22.0 & 29.0 \\
\hline \multirow[t]{2}{*}{ THI } & 66.9 & 0.83 & 64.6 & 68.3 & $78.7^{*}$ & 0.64 & 77.8 & 79.9 \\
\hline & \multicolumn{8}{|c|}{ Brown Swiss } \\
\hline AT & 20.3 & 0.76 & 18.9 & 21.2 & $30.6^{*}$ & 0.49 & 29.4 & 31.7 \\
\hline $\mathrm{RH}$ & 74.8 & 0.83 & 74.1 & 76.4 & $39.6 *$ & 3.99 & 33.0 & 53.0 \\
\hline THI & 66.9 & 1.15 & 64.9 & 68.4 & $77.2^{*}$ & 0.84 & 75.9 & 80.0 \\
\hline
\end{tabular}

Note: AT is the air temperature, ${ }^{\circ} \mathrm{C}$; $\mathrm{RH}$ is the relative humidity, \%; THI is the temperature and humidity index, units.

*Significant difference $(P<0.05)$ between the values of the indicators in the morning and the afternoon.

Table 3 Physiological indicators of dairy cows.

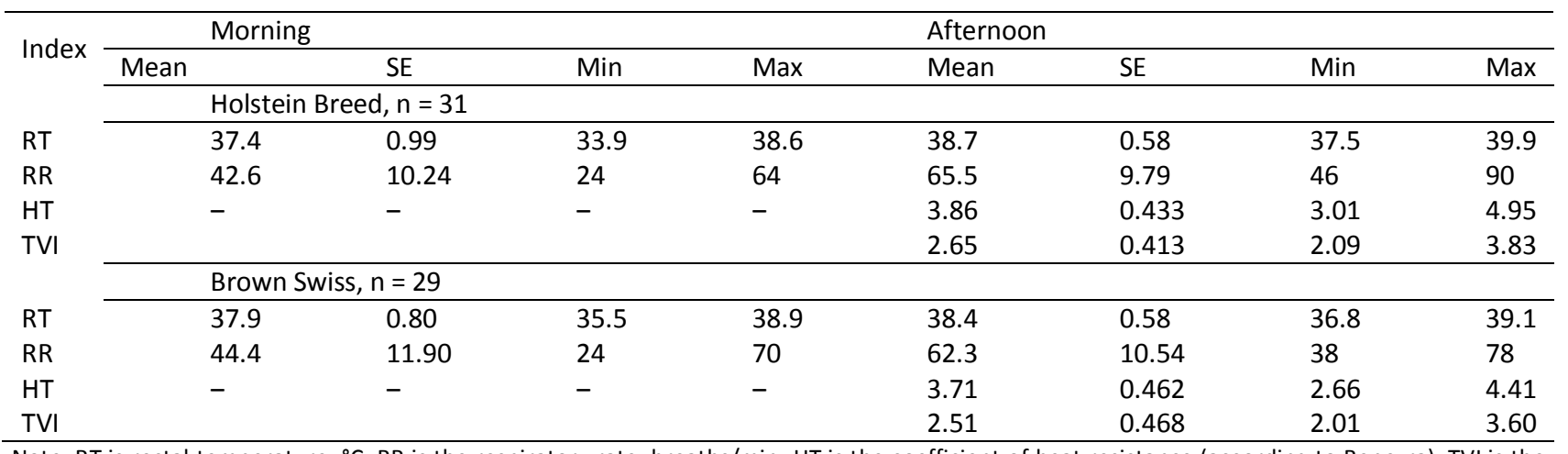

Note: RT is rectal temperature, ${ }^{\circ} \mathrm{C} ; \mathrm{RR}$ is the respiratory rate, breaths/min; $\mathrm{HT}$ is the coefficient of heat resistance (according to Benezra); TVI is the coefficient of thermal vulnerability (according to Dmitriev).

\subsection{Milk productivity of cows}

The milk productivity of HB and BS breeds in the warm season from May to September inclusively indicates (Table 4) that, compared to May (which we considered the most comfortable for animals in terms of weather conditions), in the hot summer months (especially July and August), the average daily milk yield of cows decreased.

The daily milk yield of HB cows from July to September decreased by 1.2-3.6\% compared to May. In BS cows, milk losses during this period were less, only $0.4-1.4 \%$. It is significant (Figure 1 ) that the daily milk yield in BS almost recovered to the initial level in September. In $\mathrm{HB}$, the daily milk losses per cow remained significant $(0.1 \mathrm{~kg}$ versus 0.8 $\mathrm{kg})$.

During the hot period, the main components of milk of both breeds' milk were higher than in the spring period, which is associated with an increase in milk dry matter against the background of a decrease in daily milk yield.

\section{Discussion}

\subsection{Keeping dairy cows}

The productivity and health of animals and their ability to adapt to weather conditions depend on keeping and feeding. Modern intensive milk production technologies, which are common in European countries, use free-stall housing of many dairy cows in naturally ventilated animal buildings (Algers et al 2009). They are fed with nutrientbalanced feed mixtures of corn silage and concentrates, depending on the lactation period and milk yield (NRC 2001). Although the intensive exploitation of animals on dairy farms leads to premature leaving the herd and animal health problems (Petrovic et al 2019), in our case, keeping of dairy cows in NVB and the same level of feeding on these two commercial dairy farms were favorable for studying the breed characteristics of the heat resistance of animals.

\subsection{Weather conditions and indoor climate}

Weather conditions directly affect animal welfare and productivity (Tao et al 2018). Traditionally, the effect of heat on the body of animals is assessed by the temperaturehumidity index (THI), or similar indices (for example, ETIC and TGWB index), which simultaneously take into account the effect of several weather factors on dairy cows (Dikmen and Hansen 2009; Kumar et al 2018; Yao et al 2019). However, the Temperature Humidity Index (THI), a combination of dry-bulb temperature and relative humidity, is the most common measure of heat stress used in dairy cows and is easy to use (Hammami et al 2013; Heinicke et al 2018). 
Table 4 Average daily milk yield per herd of cows in the warm season (Mean \pm SE).

\begin{tabular}{|c|c|c|c|c|c|}
\hline \multirow[t]{3}{*}{ Index } & \multicolumn{5}{|l|}{ Month ${ }^{1}$} \\
\hline & May & June & July & August & September \\
\hline & $\mathrm{THI}=63.4$ & $\mathrm{THI}=67.8$ & $\mathrm{THI}=69.5$ & $\mathrm{THI}=68.9$ & $\mathrm{THI}=61.7$ \\
\hline & \multicolumn{5}{|c|}{ Holstein Breed } \\
\hline Daily milk yield (kg) & $25.1 \pm 0.02$ & $25.2 \pm 0.02$ & $24.8 \pm 0.13^{*}$ & $24.2 \pm 0.04^{*}$ & $24.3 \pm 0.04 *$ \\
\hline Milk fat (\%) & $3.53 \pm 0.015$ & $3.46 \pm 0.014$ & $3.43 \pm 0.008^{*}$ & $3.53 \pm 0.011$ & $3.74 \pm 0.020^{*}$ \\
\hline \multirow[t]{2}{*}{ Milk protein (\%) } & $3.20 \pm 0.012$ & $3.19 \pm 0.014$ & $3.18 \pm 0,016$ & $3.18 \pm 0,015$ & $3.29 \pm 0.013$ \\
\hline & \multicolumn{5}{|l|}{ Brown Swiss } \\
\hline Daily milk yield (kg) & $28.1 \pm 0.09$ & $28.2 \pm 0.57$ & $27.7 \pm 0.08^{*}$ & $27.7 \pm 0,12^{*}$ & $28.0 \pm 0.07$ \\
\hline Milk fat (\%) & $3.47 \pm 0.006$ & $3.48 \pm 0,077$ & $3.51 \pm 0,009 *$ & $3.62 \pm 0,012$ & $3.84 \pm 0.016^{*}$ \\
\hline Milk protein (\%) & $3.29 \pm 0,006$ & $3.38 \pm 0.070$ & $3.43 \pm 0,006^{*}$ & $3.44 \pm 0.005^{*}$ & $3.46 \pm 0.004^{*}$ \\
\hline
\end{tabular}

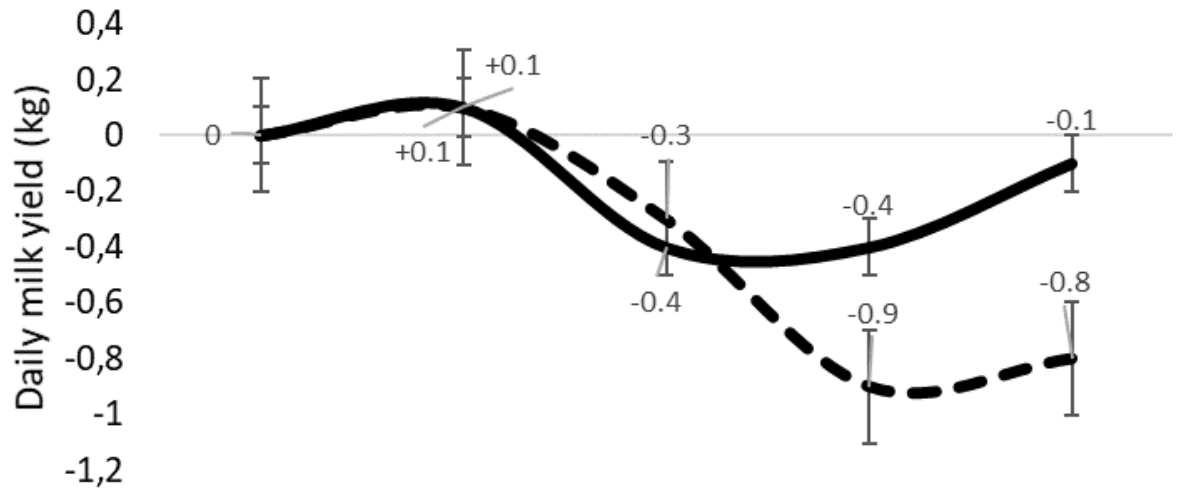

May Jun.
Months

Holstein Breed $\longrightarrow$ Brown Swiss

Figure 1 Dynamics of daily milk yield in a herd of dairy cows in the warm season, depending on the breed of animals.

At the same time, the use of meteorological data from the nearest stations at the location of farms is a generally accepted practice for assessing the impact of weather conditions on animals (Bohmanova et al 2007). However, weather conditions near livestock buildings can significantly depend on the terrain features, wind speed, and farm location above sea level (Yi et al 2018; Broucek et al 2019). Therefore, the data received from the nearest stations and the state of the air on a particular dairy farm may differ. This is also evidenced by our recent studies (Mylostyvyi et al 2020).

In addition, there is much uncertainty associated with measuring microclimate parameters when it comes to keeping dairy cows in naturally ventilated buildings (Doumbia et al 2020). The accuracy of the results varies significantly due to the non-uniform distribution of heat and humidity sources associated with equipment operation and air turbulence (Hempel et al 2018), which directly depends on environmental conditions. And although the same technique and equipment were used to determine the microclimate, we do not exclude the possibility of the influence of the design features of NVB on the accuracy of our results.

In our study, there were no significant differences in meteorological conditions between the genetic groups of animals. In addition, all the cows had the same level of feeding and productivity. Consequently, the level of production factors cannot be considered responsible for heat resistance. Therefore, the differences we found in the response of cows of the studied breeds are related to their genetic characteristics.

\subsection{Changes in the physiological parameters of animals}

Animals are susceptible to environmental conditions by changing physiological parameters. It was established (Mader et al 2006) that the correlation coefficient ( $r$ ) between $\mathrm{THI}$ and the degree of dyspnea, which was visually assessed by severity in points (from 0 - no dyspnea to 4 severe dyspnea), varied from 0.47 to 0,87 . In other studies 
(Wang et al 2018), it has been shown that Equivalent Temperature Index for Cattle (ETIC) was very good at predicting changes in physiological responses. The coefficient of determination (R2) for body temperature and respiratory rate was 0.40 and 0.49 , respectively.

Differences in ambient temperature, relative humidity, and THI between morning and afternoon, with higher temperatures and lower values of relative humidity in the afternoon, were associated with higher solar radiation. This indicates that the animals were exposed to significant heat stress, especially in the afternoon, regardless of the genetic group, since the THI was higher than the values reported for animals under thermoneutral conditions (Daltro et al 2017). Therefore, during the day, animals of all genetic groups showed physiological indicators higher than morning values.

It is well known (Amamou et al 2019) that with an increase of THI in HB cows, an increase in physiological variables such as respiration rate and rectal temperature occurs. In terms of heat load, BS cows had a lower rectal temperature and respiratory rate than HB cows, confirming other researchers who found that BS cows were more tolerant of heat stress than HB cows. In particular, during the stay in the shade throughout the hot period (Ray et al 2004), BS cows had a lower rectal temperature $\left(39.2^{\circ} \mathrm{C}\right)$ than $\mathrm{HB}$ cows $\left(39.7^{\circ} \mathrm{C}\right)$. The respiratory rate in HB was higher $(87$ breaths/min) than in BS (79 breaths/min).

Specialized dairy cows are more sensitive to hyperthermia as they generate more metabolic heat (Wangui et al 2018). For example, in Brazilian tropical conditions, mean rectal temperature (RT), respiratory rate (RR), and heart rate $(\mathrm{HR})$ were higher in $\mathrm{HB}$ cows than in local Girolando (Gir) cows and their crossbreeds with HB (Daltro et al 2017). Smith et al (2013) reported that Jersey (Jer) cows were more heat tolerant than HB cows.

It was expected that purebred HB cows would suffer more from heat stress, as this breed is less adaptable to climate change due to its higher metabolic rate and problems with heat loss. For example, compared to smaller animals that lose heat more easily (McManus et al 2009), such as Gir (Daltro et al 2017) or Jer (Smith et al 2013).

However, the comparative animals were similar in our case since BS and HB are large animals, approximately the same live weight and productivity. The nature of the differences in their response to heat stress may lie in the breed peculiarities and genes responsible for the thermal resistance of animals (Wang et al 2013; Kumar et al 2021). Thanks to easier heat dissipation and physical support, BS animals are more resistant to heat than HB (Nasr and ElTarabany 2017).

\subsection{Heat resistance and milk production of cows}

Dairy cattle are susceptible to the decrease in milk yield caused by heat stress. As the frequency and duration of heat stress events increases, long-term food security concerning dairy products is threatened. Identifying dairy cattle that are more resistant to heat stress will be an important step towards breeding dairy herds that are more adaptable to the coming climate change (Gantner et al 2016).

Most of the existing studies examining the differences between breeds in thermal tolerance have been conducted on $\mathrm{HB}$ cows, probably because they are the predominant dairy breed worldwide (Maggiolino et al 2020). Although BS cows are less numerous worldwide than HB cows, they are widely used for cheese production due to the composition of milk components.

With an increase of THI in dairy cows, there is a decrease in milk, fat, and protein yields (Amamou et al 2019). The reduction in daily milk yield in dairy cows by $0.3-0.9 \mathrm{~kg}$, found in our study, is confirmed in the works of other researchers. Maggiolino et al (2020), calculating daily milk loss based on standardized $4 \%$ milk fat, reports that an increase in THI above the threshold per unit was accompanied by a decrease in milk yield in the range of 0.38$1.00 \mathrm{~kg} /$ day per BS cow. Similar values for milk yield at lower $\mathrm{THI}$ thresholds have been reported in HB cows. In the Mediterranean Basin, losses were $0.41 \mathrm{~kg} /$ day with $\mathrm{THI}$ values slightly higher than 69 (Bouraoui et al 2002); from 0.43 to $1.27 \mathrm{~kg} /$ day at THI greater than 70 (Bernabucci et al 2014) and even with THI values somewhat greater than 55 - by 0.13 $\mathrm{kg} /$ day (Amamou et al 2019).

The established THI thresholds for milk yield, milk fat, and protein content indicate that BS has higher thermal stability than the literature values given for $\mathrm{HB}$ cows (Heinicke et al 2018). As the THI increases, BS cows tend to produce the same volume of milk but with a deterioration in the quality of the components (Maggiolino et al 2020), which, in principle, is demonstrated by our study (Figure 1).

These differences between BS and HB in terms of milk yield dynamics can be associated with different metabolic reactions of animals and the mammary gland to $\mathrm{HS}$, as reported in their work by Maggiolino et al (2020). However, we still lack complete knowledge of the mechanisms of hyperthermia that negatively affect milk synthesis, given that environmental conditions affect the organism of an animal as a whole (Amamou et al 2019).

According to Dikmen et al (2012), the heritability coefficient of body temperature in dairy cows is 0.17 , with a decrease in milk yield at HS - 0.19 (Nguyen et al 2016). Since the sensitivity of animals to HS varies depending on genetic factors, genetic methods can solve HS problems in animal husbandry (Binsiya et al 2016). Thermal tolerance selection can be accelerated by genomic selection using complete genome DNA markers that predict heat stress tolerance (Gantner et al 2016). This approach, although long term, will improve the adaptation of animals to excessive heat stress, so the creation and breeding of thermotolerant species can be a good strategy in the fight against HS.

\section{Conclusions}

Evaluation of the heat resistance of dairy cows revealed differences in the dynamics of physiological parameters with an increase in THI above the comfort limit. $\mathrm{HB}$ cows responded to heat load with a more significant 
increase in RT and RR. The best values of the indices characterizing heat resistance (HT and TVI) were recorded in BS cows, which were also characterized by lower daily milk yield losses during the summer heat in the continental climate of Ukraine. The discovered interbreed differences in the organism's thermal stability require further clarification of their biological and genetic nature.

\section{Conflict of Interest}

The authors declare that they have no conflict of interest.

\section{Funding}

This research did not receive any financial support.

\section{References}

Abdela N, Jilo K (2016) Impact of climate change on livestock health: A review. Global Veterinaria 16:419-424.

Algers B, Bertoni G, Broom D, Hartung J, Lidfors L, Metz J, Munksgaard L, Pina TN, Oltenacu P, Rehage J, Rushen J (2009) Effects of farming systems on dairy cow welfare and disease. Scientific report of EFSA prepared by the Animal Health and Animal Welfare Unit on the effects of farming systems on dairy cow welfare and disease. Annex to the EFSA Journal 1143:1-38.

Amamou H, Beckers Y, Mahouachi M, Hammami H (2019) Thermotolerance indicators related to production and physiological responses to heat stress of Holstein cows. Journal of Thermal Biology 82:90-98. doi:10.1016/j.jtherbio.2019.03.016

Benezra MV (1954) A new index measuring the adaptability of cattle to tropical conditions. Journal of Animal Science 13:1015.

Bernabucci U, Biffani S, Buggiotti L, Vitali A, Lacetera N, Nardone A (2014) The effects of heat stress in Italian Holstein dairy cattle. Journal of Dairy Science 97:471-486. doi:10.3168/jds.2013-6611

Binsiya TK, Sejian V, Bagath M, Krishnan G, Hyder I, Manimaran A, Lees AM, Gaughan JB, Bhatta R (2016) Significance of hypothalamic-pituitary-adrenal axis to adapt to climate change in livestock. International Research Journal of Agricultural and Food Sciences 2:1-20.

Broucek J, Ryba S, Dianova M, Uhrincat M, Soch M, Sistkova M, Mala G, Novak P (2019) Effect of evaporative cooling and altitude on dairy cows milk efficiency in lowlands. International Journal of Biometeorology 64:433-444. doi:10.1007/s00484-019-01828-5

Daltro D dos S, Fischer V, Alfonzo EPM, Dalcin VC, Stumpf MT, Kolling GJ, Silva MVGB da, McManus C (2017) Infrared thermography as a method for evaluating the heat tolerance in dairy cows. Revista Brasileira de Zootecnia 46: 374-383. doi:10.1590/s1806-92902017000500002

Das R, Sailo L, Verma N, Bharti P, Saikia J, Imtiwati, Kumar R (2016) Impact of heat stress on health and performance of dairy animals: A review. Veterinary World 9:260-268. doi:10.14202/vetworld.2016.260-268

Dikmen S, Hansen PJ (2009) Is the temperature-humidity index the best indicator of heat stress in lactating dairy cows in a subtropical environment? Journal of Dairy Science 92:109-116. doi:10.3168/jds.2008-1370

Dikmen S, Cole JB, Null DJ, Hansen PJ (2012) Heritability of rectal temperature and genetic correlations with production and reproduction traits in dairy cattle. Journal of Dairy Science 95:3401-3405. doi:10.3168/jds.2011-4306

Dmitriev AF (1970) The role of natural resistance in the acclimatization of farm animals. Proceedings of the Tselinograd Agricultural Institute 8: 27-34.

Doumbia EM, Janke D, Yi Q, Zhang G, Amon T, Kriegel M, Hempel S (2021) On Finding the Right Sampling Line Height through a Parametric Study of Gas Dispersion in a NVB. Applied Sciences 11:4560. doi:10.3390/app11104560

Ferreira FC, Gennari RS, Dahl GE, De Vries A (2016) Economic feasibility of cooling dry cows across the United States. Journal of Dairy Science 99:99319941. doi:10.3168/jds.2016-11566
Gantner V, Mijić P, Kuterovac K, Solić D, Gantner R (2011) Temperaturehumidity index values and their significance on the daily production of dairy cattle. Daily production of dairy cattle. Mljekarstvo 61:56-63.

Garner JB, Douglas ML, Williams SRO, Wales WJ, Marett LC, Nguyen TTT, Reich CM, Hayes BJ (2016) Genomic Selection Improves Heat Tolerance in Dairy Cattle. Scientific Reports 6. doi:10.1038/srep34114

Hammami H, Bormann J, M'hamdi N, Montaldo HH, Gengler N (2013) Evaluation of heat stress effects on production traits and somatic cell score of Holsteins in a temperate environment. Journal of Dairy Science 96:18441855. doi:10.3168/jds.2012-5947

Heinicke J, Hoffmann G, Ammon C, Amon B, Amon T (2018) Effects of the daily heat load duration exceeding determined heat load thresholds on activity traits of lactating dairy cows. Journal of Thermal Biology 77:67-74. doi:10.1016/j.jtherbio.2018.08.012

Kibler HH (1964) Thermal efects of various temperature-humidity combinations on Holstein cattle as measured by eight physiological responses. Environmental physiology and shelter engineering. Agricultural Experiment Station, Missouri, pp. 1-42.

Kim WS., Lee J-S, Jeon SW, Peng DQ, Kim YS, Bae MH, Jo YH, Lee HG (2018) Correlation between blood, physiological and behavioral parameters in beef calves under heat stress. Asian-Australasian Journal of Animal Sciences 31:919-925. doi:10.5713/ajas.17.0545

Kumar R, Gupta ID., Verma A, Singh S, Kumari R, Verma, N (2021) Genetic polymorphism in HSPB6 gene and their association with heat tolerance traits in Indian Karan Fries (Bos taurus x Bos indicus) cattle. Animal Biotechnology, 1-12. doi:10.1080/10495398.2021.1899939

Mader TL, Davis MS, Brown-Brandl T (2006) Environmental factors influencing heat stress in feedlot cattle. Journal of Animal Science 84:712719. doi:10.2527/2006.843712x

Maggiolino A, Dahl GE, Bartolomeo N, Bernabucci U, Vitali A, Serio G, Cassandro M, Centoducati G, Santus E, De Palo P (2020) Estimation of maximum thermo-hygrometric index thresholds affecting milk production in Italian Brown Swiss cattle. Journal of Dairy Science 103:8541-8553. doi:10.3168/jds.2020-18622

McManus C, Prescott E, Paludo GR, Bianchini E, Louvandini H, Mariante AS (2009) Heat tolerance in naturalized Brazilian cattle breeds. Livestock Science 120:256-264. doi:10.1016/j.livsci.2008.07.014

Mylostyvyi R, Chernenko o (2019). Correlations between environmental factors and milk production of Holstein cows. Data 4:103. https://doi.org/10.3390/ data4030103.

Mylostyvyi R, Izhboldina O, Chernenko O, Khramkova O, Kapshuk N, Hoffmann G (2020) Microclimate modeling in naturally ventilated dairy barns during the hot season: Checking the accuracy of forecasts. Journal of Thermal Biology 93:102720. doi:10.1016/j.jtherbio.2020.102720

Nasr MAF, El-Tarabany MS (2017) Impact of three THI levels on somatic cell count, milk yield and composition of multiparous Holstein cows in a subtropical region. Journal of Thermal Biology, 64:73-77. doi:10.1016/j.jtherbio.2017.01.004

Nguyen TTT, Bowman PJ, Haile-Mariam M, Pryce JE, Hayes BJ (2016) Genomic selection for tolerance to heat stress in Australian dairy cattle. Journal of Dairy Science, 99:2849-2862. doi:10.3168/jds.2015-9685

Nutrient Requirements of Dairy Cattle (2001). doi:10.17226/9825

Petrovic M, Rakonjac S, Bogdanovic V, Bogosavljevic-Boskovic S, Djokovic R, Djedovic R, Petrovic M (2019) Effect of non-genetic factors on longevity traits in Simmental cows. Biotechnology in Animal Husbandry 35:229-241. doi:10.2298/bah1903229p

Rashamol VP, Sejian V, Bagath M, Krishnan G, Archana PR, Bhatta R (2018) Physiological adaptability of livestock to heat stress: an updated review. Journal of Animal Behaviour and Biometeorology 6:62-71. doi:10.31893/2318-1265jabb.v6n3p62-71

Ray D, Correa-Calderon A, Armstrong D, Enns M, DeNise S, Howison C. (2004) Thermoregulatory responses of Holstein and Brown Swiss Heat-Stressed dairy cows to two different cooling systems. International Journal of Biometeorology 48:142-148. doi:10.1007/s00484-003-0194-y 
Smith DL, Smith T, Rude BJ, Ward SH (2013) Short communication: Comparison of the effects of heat stress on milk and component yields and somatic cell score in Holstein and Jersey cows. Journal of Dairy Science 96:3028-3033. doi:10.3168/jds.2012-5737

Tomczyk AM, Bednorz E, Półrolniczak M (2019) The occurrence of heat waves in Europe and their circulation conditions. Geografie 124:1-17. doi:10.37040/geografie2019124010001

Wang X, Gao H, Gebremedhin KG, Bjerg BS, Van Os J, Tucker CB, Zhang G (2018) A predictive model of equivalent temperature index for dairy cattle (ETIC). Journal of Thermal Biology 76:165-170.
Wang Y, Huang J, Xia P, He J, Wang C, Ju Z, Li J, Li R, Zhong J, Li Q (2013) Genetic variations of HSBP1 gene and its effect on thermal performance traits in Chinese Holstein cattle. Molecular Biology Reports 40:3877-3882.

Wangui JC, Bebe BO, Ondiek JO, Oseni SO (2018) Application of the climate analogue concept in assessing the probable physiological and haematological responses of Friesian cattle to changing and variable climate in the Kenyan Highlands. South African Journal of Animal Science 48:572.

Yi, Q., Zhang, G., König, M., Janke, D., Hempel, S., \& Amon, T. (2018). Investigation of discharge coefficient for wind-driven naturally ventilated dairy barns. Energy and Buildings, 165, 132-140. 